\title{
Analysis of Antiemetic Premedication Administration Timing on Nausea and Vomiting Incidence among Breast Cancer Patients Receiving Chemotherapy
}

\author{
Mahardian Rahmadi ${ }^{1}$, Indira D. Kharismawati ${ }^{2}$, Heru Purwanto ${ }^{3}$, Irvina Harini ${ }^{4}$, \\ Suharjono $^{1}$, Chris Alderman ${ }^{1,5}$ \\ ${ }^{1}$ Department of Clinical Pharmacy, Universitas Airlangga, Surabaya, Indonesia, ${ }^{2}$ Master of Clinical \\ Pharmacy, Universitas Airlangga, Surabaya, Indonesia, ${ }^{3}$ Division of Oncology Surgery, \\ Department of Surgery, Dr. Soetomo General Hospital, Surabaya, Indonesia/Faculty of Medicine, \\ Universitas Airlangga, Surabaya, Indonesia, ${ }^{4}$ Department of Pharmacy, Installation of Pharmacy, \\ Dr. Soetomo General Hospital, Surabaya, Indonesia, ${ }^{5}$ School of Pharmacy and Medical Sciences, \\ University of South Australia, Adelaide, Australia
}

\begin{abstract}
The risk factors affecting chemotherapy-induced nausea and vomiting (CINV) includes antiemetic premedication time pattern, and this study investigates the capability of enhancing this in breast cancer patients receiving high emetogenic chemotherapy (HEC). Furthermore, this observational research was implemented at the oncology unit of Dr. Soetomo General Hospital Surabaya over a three-month period involving 69 female patients. The results showed unspecific antiemetic premedication timing in comparison to those with recommended timeframes, was connected with greater occurrence of both acute nausea in all cycles of chemotherapy $(\mathrm{p}<0.05)$, and acute vomiting in second and third cycles $(p<0.05)$ but not in the first cycle $(p=0.49)$. However, specific time administration of antiemetic treatment was linked with lower incidence of delayed nausea in all cycles $(p<0.05)$, and less delayed vomiting in second and third cycles $(\mathrm{p}<0.05)$ but not in first cycle $(\mathrm{p}=0.10)$. These findings indicate specific time administration of antiemetic drugs causes significant advantages in mitigating CINV among breast cancer patients treated with emetogenic chemotherapy, and significantly lessened the occurrence of acute and delayed nausea and vomiting.
\end{abstract}

Keywords: Antiemetic premedication timing, breast cancer, CINV, nausea and vomiting

\section{Analisis Waktu Pemberian Premedikasi Antiemetik terhadap Kejadian Mual Muntah pada Pasien Kanker Payudara yang Mendapatkan Kemoterapi}

\begin{abstract}
Abstrak
Kemoterapi dapat menginduksi mual muntah (chemotherapy-induced nausea and vomiting, CINV) yang dipengaruhi oleh beberapa faktor. Salah satu faktornya adalah waktu pemberian premedikasi antiemetik yang dapat meningkatkan kejadian CINV pada pasien kanker payudara yang menerima kemoterapi. Studi ini menganalisis waktu pemberian premedikasi antiemetik terhadap kejadian mual dan muntah yang terjadi pada pasien kanker payudara yang mendapatkan kemoterapi dengan tingkat emetogenik yang tinggi. Penelitian ini merupakan penelitian observasional prospektif dilakukan di Poli Onkologi Satu Atap RSUD Dr. Soetomo Surabaya selama periode pengambilan data tiga bulan dan melibatkan 69 wanita kanker payudara yang mendapat kemoterapi dengan tingkat emetogenik yang tinggi. Pemberian premedikasi antiemetik dengan waktu yang tidak spesifik, meningkatkan kejadian mual akut pada semua siklus dengan $\mathrm{p}<0,05$ dan pada kejadian muntah akut pada siklus kedua dan ketiga $(\mathrm{p}<0,05)$, namun tidak pada siklus pertama kemoterapi $(p=0,49)$. Pemberian premedikasi antiemetik dengan waktu spesifik dapat menurunkan kejadian mual tertunda di siklus pertama hingga ketiga $(p<0,05)$ dan pada kejadian muntah tertunda pada siklus kedua dan ketiga $(\mathrm{p}<0,05)$, namun tidak pada siklus pertama $(\mathrm{p}=0,10)$. Penelitian ini memberikan bukti bahwa premedikasi antiemetik yang diberikan dengan waktu spesifik memberikan manfaat dalam mengurangi kejadian CINV yang berpotensi pada pasien kanker payudara yang mendapatkan kemoterapi dengan tingkat emetogenik tinggi.
\end{abstract}

Kata kunci: CINV, kanker payudara, mual dan muntah, waktu pemberian premedikasi antiemetik

Correspondence: apt. Mahardian Rahmadi, S.Si., M.Sc., PhD., Department of Clinical Pharmacy, Universitas Airlangga, Surabaya, East Java 60115, Indonesia, email: mahardianr@ff.unair.ac.id

Submitted: $31^{\text {st }}$ March 2020, Accepted: $15^{\text {th }}$ October 2020, Published: $9^{\text {th }}$ December 2020 


\section{Introduction}

One of the most prevalent types of neoplasm is breast cancer. About 50\% of Indonesian women suffered from breast cancer have their disease diagnosed at an advanced stage. ${ }^{1,2}$ The standard treatment for breast cancer involves the use of chemotherapy. ${ }^{3}$ Combination chemotherapy regimens are associated with higher response rates compared to singleagent therapies. In addition, it is often associated with chemotherapy induced nausea and vomiting (CINV), serious adverse effect that is able to negatively impact upon patients quality of life (QoL) and how they could allow and comply with therapy. ${ }^{4-6}$ The known patient-related risk factors involves young age, female gender, low alcohol intake history, and prior adverse experience with chemotherapy. ${ }^{7-9}$ Anthracycline-based chemotherapy is categorized as a highly emetogenic chemotherapy (HEC). ${ }^{10}$ Some chemotherapy drugs are highly emetogenic ( $>90 \%$ frequency of emesis, for instance, cisplatin and combination anthracycline with cyclophosphamide), moderate emetic risk (30-90\% frequency of emesis, for instance, cyclophosphamide, carboplatin, and epirubicin), low emetic risk (10-30\% frequency of emesis, for instance, etoposide) and minimal emetic risk $(<10 \%$ frequency of emesis, for instance, bleomycin). ${ }^{11-13}$ The combinations of several chemotherapeutics agents can increase CINV activity. CINV prevention and treatment is a prevention against CINV and antiemetic given to patients receiving chemotherapy. ${ }^{14}$

CINV is associated with significant decline in their life quality and is perceived by patients as one of the most important adverse effects associated with cancer treatment. ${ }^{6}$ Risk factors for developing CINV are classified as patient or treatment-related. Meanwhile, some variability could be observed in patient risk factors on the basis of chemotherapy regimen, the common patient-related factors including younger age, female, lower history of alcohol use ( $<5$ standard drinks per week), emesis with prior chemotherapy and a dosing schedule of premedication antiemetic that covers both acute and delayed emesis. ${ }^{7,8}$ CINV can be subdivided as acute and delayed. Acute onset nausea and vomiting usually follow within a few minutes to several hours after drug administration. In addition, this commonly resolves within the first 24 hours. After 5 to 6 hours, the intensity of acute emesis generally is at its peak. The incidence of acute emesis related to CINV is high on younger women with lower ethanol usage and had experienced CINV before. The dose of emetogenic agent and antiemetic regimen also contribute to the incidence of CINV. On the other hand, delayed nausea and vomiting usually occurs in the period 24-120 hours after chemotherapy. ${ }^{8,10,15}$

National Comprehensive Cancer Network (NCCN) guidelines provide a classification that addresses the likelihood of CINV that is primarily related to the emetogenic potential of the specific chemotherapeutic agents applied. Patient who got acute emesis and did not take any antiemetic prophylaxis, therefore the chemotherapeutic agents can be classified into four types. The first is high emetic risk (higher than $90 \%$ of patients experiencing acute emesis: e.g. combination of anthracycline and cyclophosphamide, cisplatin, and cyclophosphamide $>1500 \mathrm{mg} /$ $\mathrm{m}^{2}$ ); the second one is moderate emetic risk (30-90\% of patients suffering acute emesis: e.g. carboplatin, cyclophosphamide 1500 $\mathrm{mg} / \mathrm{m}^{2}$, daunorubicin, doxorubicin, epirubicin, and ifosfamide); the third one is low emetic risk (10-30\% of patients with acute emesis: e.g. cytarabine 100-200 mg/m², docetaxel, etoposide, 5-fluorouracil, gemcitabine, and paclitaxel); and the fourth is minimal emetic risk (fewer than $10 \%$ of patients experience acute emesis: e.g. bleomycin, vinblastine, 
vincristine, and vinorelbine). ${ }^{8,13,15}$ The common way to prevent chemotherapyinduced nausea and vomiting is by performing antiemetic therapy before chemotherapy. The antiemetic therapy should also be continued for the same period as the duration of the emetic activity of the chemotherapeutic agent being used. ${ }^{16}$ The acute CINV occurs within 1-2 hours of chemotherapy administration and can last for up to 24 hours, the delayed CINV presents more than 24 hours until 120 hours periods after chemotherapy administration. ${ }^{17}$ The antiemetic premedication has reduced the vomiting prevalence considerably, but the evaluation shows that approximately $60.7 \%$ of patients still undergo either acute or delayed nausea following the chemotherapy. ${ }^{18}$

At oncology unit of Dr. Soetomo General Hospital, antiemetic regimen used during highly emetogenic chemotherapy includes a 5-Hydroxytrptamine (5-HT3) receptor antagonist (ondansetron), a corticosteroid (dexamethasone), an antihistamine (diphenhydramine) and an $\mathrm{H} 2$ receptor antagonist (ranitidine). Dr. Soetomo General Hospital adopts antiemetic premedication protocol of NCCN version 2.2017 guideline. The protocol is applied on cancer patients receiving high emetogenic chemotherapy (HEC), namely 5- $\mathrm{HT}_{3}$ (ondansetron 8-16 mg intravenous administration), antagonist NK-1 (aprepitant $125 \mathrm{mg}$ per oral administration), and dexamethasone $12 \mathrm{mg}$ (intravenous or per oral administration). ${ }^{19}$ However, antagonist NK-1 (aprepitant) is not widely available in Indonesia, therefore the protocol is modified by adding ranitidine and diphenhydramine. Ranitidine inhibits $\mathrm{H} 2$ receptors and minimizes gastric acids secretion resulting in preventing nausea and vomiting, while diphenhydramine inhibits $\mathrm{H} 1$ receptors and to reduce vestibular stimulation and thus preventing nausea and vomiting. ${ }^{20}$ Although this type of regimen is known to be effective in preventing nausea and vomiting by chemotherapy with low emetogenic potential, previous study suggests that this approach may not be effective for patients who received chemotherapy with moderate and high emetogenic levels. ${ }^{13,19}$

Antiemetic premedication timing is one of the risk factors increasing $\mathrm{CINV}$ incidence. According to US National Cancer Institute, antiemetic premedication (ondansetron) must be administered within 15-30 minutes before chemotherapy to prevent nausea and vomiting. ${ }^{21}$ The administration timing is determined based on ondansetron onset of action to prevent nausea and vomiting. Based on this introduction, this study analyzes whether specific time administration of antiemetic premedication can reduce nausea and vomiting incidence of breast cancer patients receiving high emetogenic chemotherapy.

\section{Methods}

This was a prospective observational study analyzing antiemetic premedication administration timing on nausea and vomiting incidence of breast cancer patients, who receiving high emetogenic chemotherapy at oncology unit of Dr. Soetomo General Hospital Surabaya. However, the purpose of this study was not to investigate differential effect of antiemetic premedication timing on nausea and vomiting incidence. This study was declared ethical by the health research ethics committee of Dr. Soetomo General Hopital Surabaya with approval number 100/ Panke.KKE/II/2016.

The participants recruited in this study were women with breast cancer underwent their first chemotherapy cycle with antiemetic premedication as prophylaxis between March to April 2016. The inclusion criteria of this study were breast cancer patients receiving chemotherapy since the first cycle, who never done any chemotherapy before and receiving 
antiemetic premedication as prophylaxis of emesis. All patients were observed from first until the third cycle of chemotherapy and interviewed from the first cycle through the third cycle of chemotherapy. The exclusion criteria were breast cancer patients that receives chemotherapy without antiemetic premedication and the breast cancer patients receiving chemotherapy but not from the first cycle. Meanwhile, the drop out criteria were breast cancer patients who passed away during the research, withdrawing their participation from this research, and those who were not continuing their chemotherapy treatment.

Antiemetic premedication (ondansetron) was given 15 until 30 minutes before chemotherapy which was considered specific time, while less than 15 minutes and more than 30 minutes of antiemetic administration was considered unspesific time. Antiemetic premedication administration time refers to the interval between the end of antiemetic (ondansetron) administration to the start of chemotherapy. The subjects were followed from first until third chemotherapy cycle and underwent structured interview by a pharmacist to evaluate the response to antiemetic treatment. After completing each cycle of chemotherapy, patient filled questionnaire. The observation was conducted for five days after chemotherapy being held. The interview was carried out on every cycle of chemotherapy (first cycle, second cycle, and third cycle). The patients are interviewed twice per cycle, namely 24 hours after chemotherapy (acute CINV) and 120 hours after chemotherapy (delayed CINV) (Figure 1). Then, the analysis of antiemetic premedication timing on nausea and vomiting was performed. The incidence of nausea and vomiting that occurred during the acute and delayed time frames was assessed using a shortened Indonesian language version of the

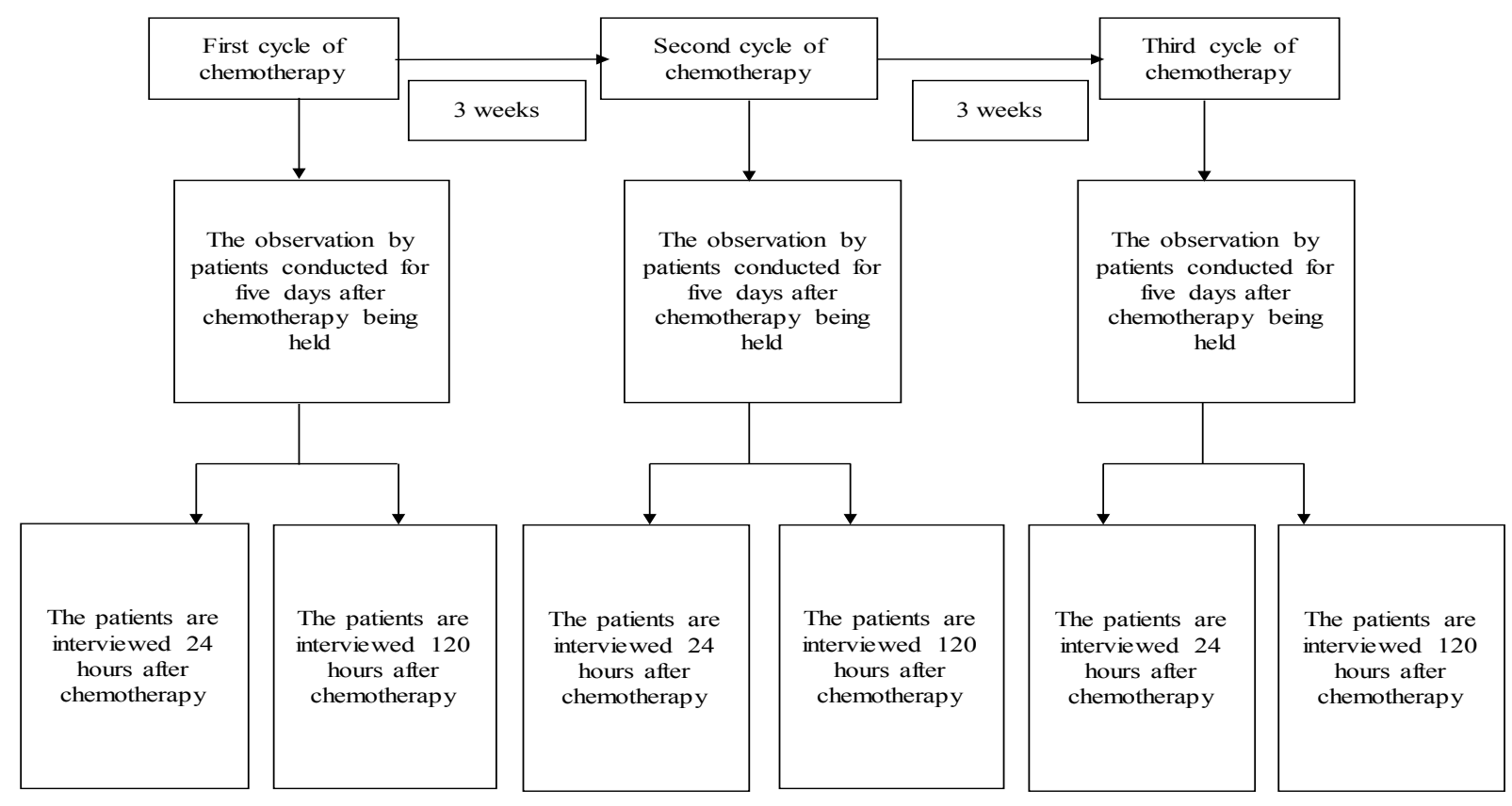

Figure 1 The Observation Workflow during Collecting Patient's Data with Acute and Delayed Nausea Vomiting after Chemotherapy

Patient interview was carried out on every cycle of chemotherapy (first cycle, second cycle, and third cycle). The patients were interviewed twice per cycle, namely 24 hours after chemotherapy (acute chemotherapy induced nausea and vomiting (CINV)) and 120 hours after chemotherapy (delayed CINV). 
assessment of antiemetic efficacy and safety questionnaire with NCI-CTCAE version 4.03 guideline to assess the grade of nausea and vomiting. ${ }^{10,22,23}$ Mann-Whitney test was used to analyze each variable between the groups. Statistical analysis were computed on a significance level of $5 \%$.

\section{Results}

During the data capture period, 72 women proceeded to receive chemotherapy, with 3 subjects who dropped out (one deceased, two declining interview) leaving 69 patients who proceeded to evaluation. All patients were women, with $17 \%$ aged $<40$ years old, $74 \%$ aged $40-60$ years old, and $9 \%$ aged $>60$ years old. A variety of chemotherapy regimens were used, all of which were classified as highly emetogenic ( $85 \%$ was treated using Cyclophosphamide, Adriamycin, Fluorouracil; 12\% using Cyclophosphamide, Epirubicin, Fluorourcil; or 3\% using Cyclophosphamide, Adriamycin). All patients received the same antiemetic premedication combination. First, ranitidine $50 \mathrm{mg}$ in $8 \mathrm{ml}$ normal saline was given intravenous bolus injection. Second, diphenhydramine $10 \mathrm{mg}$ in $4 \mathrm{ml}$ normal saline was given intravenous bolus injection. Third, dexamethasone $20 \mathrm{mg}$ in $100 \mathrm{ml} \mathrm{D5 \%}$ with intravenous drips for 15 minutes. The fourth, ondansetron $8 \mathrm{mg}$ in $50 \mathrm{ml}$ normal saline administered through intravenous drips for 10 minutes (Table 1).

The distribution of timing for the administration of antiemetic premedication was highly variable. The range of antiemetic premedication administration time was within 15 minutes until more than 2 hours before chemotherapy. Most of patients received unspecific antiemetic premedication timing, whereas only small amount of patients that had specific time administration of antiemetic premedication.

The analysis of antiemetic premedication timing on the prevalence of acute nausea and vomiting at first, second, and third cycles of chemotherapy could be seen at Table 2, 3, 4 , and 5. Those tables showed that either in acute or delayed CINV, unspecific antiemetic premedication timing significantly increased the acute and delayed nausea and vomiting. Unspecific antiemetic premedication timing was associated with a greater prevalence of acute nausea all cycles of chemotherapy $(p<0.05)$ and with a greater prevalence of acute vomiting in second and third cycles $(p<0.05)$ but not in first cycle of chemotherapy $(p=0.49)$. Specific time administration of antiemetic treatment was associated with a lower prevalence of delayed nausea in all cycles $(p<0.05)$, as well as a lower prevalence of delayed vomiting in second and third cycles $(p<0.05)$ but not in first cycle of chemotherapy $(\mathrm{p}=0.10)$.

\section{Discussion}

Breast cancer is a common malignancy in Indonesia and around the world. ${ }^{24}$ CINV associated with cytotoxic chemotherapy in this context has a potentially major role upon well being, treatment tolerability and overall treatment outcomes. ${ }^{6}$ The use of chemotherapy can produce nausea and vomiting. These particularly unpleasant impressions continue to be a problem despite better antiemetic. . $^{25,26}$ The main objective of this study was to analyze antiemetic premedication administration timing on nausea and vomiting incidence of breast cancer patients, who received high emetogenic chemotherapy in oncology unit in Dr. Soetomo General Hospital Surabaya. This prospective observational study was carried out due to the limited number of nurses working at chemotherapy ward and the time difference between antiemetic premedication and chemotherapy regimens transfer from pharmacy unit to chemotherapy wards. The time difference caused interval between 
Table 1 Patients Characteristic

\begin{tabular}{|c|c|c|}
\hline Characteristics & Total & Percentage $(\%)$ \\
\hline \multicolumn{3}{|l|}{ Age } \\
\hline$<40$ years & 12 & 17.00 \\
\hline $40-60$ years & 51 & 74.00 \\
\hline$>60$ years & 6 & 9.00 \\
\hline (Average $\pm \mathrm{SD})$ & \multirow{2}{*}{\multicolumn{2}{|c|}{$\begin{array}{c}(48 \pm 8.92) \\
(22-66)\end{array}$}} \\
\hline (Range min-max) & & \\
\hline \multicolumn{3}{|l|}{ Gender } \\
\hline Female & 69 & 100.00 \\
\hline Male & 0 & 0.00 \\
\hline \multicolumn{3}{|l|}{ Type of Cancer } \\
\hline Breast cancer & 69 & 100.00 \\
\hline \multicolumn{3}{|l|}{ Chemotherapy Regimen } \\
\hline Cyclophosphamide, Adriamycin, Fluorouracil (CAF) & 59 & 85.00 \\
\hline Cyclophosphamide, Epirubicin, Fluorourcil (CEF) & 8 & 12.00 \\
\hline Cyclophosphamide, Adriamycin (CA) & 2 & 3.00 \\
\hline \multicolumn{3}{|l|}{ Level of Emetogenic Chemotherapy } \\
\hline High emetogenic chemotherapy & 69 & 100.00 \\
\hline Moderate emetogenic chemotherapy & 0 & 0.00 \\
\hline Low emetogenic chemotherapy & 0 & 0.00 \\
\hline Minimal emetogenic chemotherapy & 0 & 0.00 \\
\hline \multicolumn{3}{|l|}{ Dose of Chemotherapy } \\
\hline CAF 600/60/600 & 1 & 1.45 \\
\hline CAF 600/70/750 & 1 & 1.45 \\
\hline CAF 605/60/600 & 1 & 1.45 \\
\hline CAF 700/70/700 & 12 & 17.39 \\
\hline CAF $750 / 75 / 750$ & 16 & 23.18 \\
\hline CAF 790/79/790 & 1 & 1.45 \\
\hline CAF 800/70/750 & 4 & 5.80 \\
\hline CAF 800/70/1000 & 6 & 8.69 \\
\hline CAF 800/75/750 & 1 & 1.45 \\
\hline CAF $800 / 80 / 800$ & 14 & 20.29 \\
\hline CAF $850 / 85 / 850$ & 1 & 1.45 \\
\hline CAF 900/90/900 & 1 & 1.45 \\
\hline $70 / 800$ & 2 & 2.90 \\
\hline CEF 700/70/700 & 2 & 2.90 \\
\hline CEF $750 / 75 / 750$ & 2 & 2.90 \\
\hline CEF 800/80/800 & 2 & 2.90 \\
\hline CEF 850/85/850 & 1 & 1.45 \\
\hline CEF $1000 / 80 / 1000$ & 1 & 1.45 \\
\hline \multicolumn{2}{|l|}{ Combination Antiemetic Premedication } & Ranitidine $50 \mathrm{mg}$ in $8 \mathrm{ml}$ normal saline \\
\hline Diphenhydramine $10 \mathrm{mg}$ in $4 \mathrm{ml}$ normal saline & 69 & 100.00 \\
\hline \multicolumn{3}{|l|}{ Dexamethasone $20 \mathrm{mg}$ in $100 \mathrm{ml} \mathrm{D} 5 \%$} \\
\hline Ondansetron $8 \mathrm{mg}$ in $50 \mathrm{ml}$ normal saline & & \\
\hline
\end{tabular}


Table 2 The Analysis of Antiemetic Premedication Timing on Incident of Acute Nausea

\begin{tabular}{|c|c|c|c|c|}
\hline \multirow{2}{*}{ Cycle } & \multirow{2}{*}{ Antiemetic Premedication Timing } & Nausea & Negligible & \multirow{2}{*}{$\mathbf{p}$} \\
\hline & & n (patient) & n (patient) & \\
\hline \multirow[t]{2}{*}{1} & Specific time & 0 & 6 & \multirow{2}{*}{$<0.05$} \\
\hline & Unspecific time & 36 & 27 & \\
\hline \multirow[t]{2}{*}{2} & Specific time & 0 & 13 & \multirow{2}{*}{$<0.05$} \\
\hline & Unspecific time & 32 & 24 & \\
\hline \multirow[t]{2}{*}{3} & Specific time & 2 & 29 & \multirow{2}{*}{$<0.05$} \\
\hline & Unspecific time & 25 & 13 & \\
\hline
\end{tabular}

*This research used Mann-Whitney test; Unspecific antiemetic premedication timing was associated with a greater prevalence of acute nausea all cycles of chemotherapy with $\mathrm{p}<0.05$.

antiemetic premedication (ondansetron) and chemotherapy drugs administration. This study also intended to observe and evaluate the nurses awareness of the important of time interval between antiemetic premedication and chemotherapy regimens administration.

This study controlled several risk factors including all patients were female breast cancer patients, and all of them received HEC. This observation was carried out starting from the first cycle of chemotherapy in order to have the same history of CINV, and all patients received the same antiemetic premedication. This was controlled to obtain homogeneous patients thereby reducing the bias. This research has demonstrated that unspecific time administration of antiemetic premedication was associated with compromised antiemetic treatment efficacy, to some extent in the acute stage and more prominently in the late phase.
Dr. Soetomo General Hospital adopts antiemetic premedication protocol of NCCN version 2.2017 guideline, which is applied on cancer patients receiving HEC, namely $5-\mathrm{HT}_{3}$ (ondansetron $8-16 \mathrm{mg}$ intravenous administration), antagonist NK-1 (aprepitant $125 \mathrm{mg}$ per oral administration), and dexamethasone $12 \mathrm{mg}$ (intravenous or per oral administration). ${ }^{19}$ Since aprepitant is not available in Indonesia, Dr. Soetomo General Hospital adjusts antiemetic premedication protocol by administering $5-\mathrm{HT}_{3}$ (ondansetron $8 \mathrm{mg}$ ), dexamethasone $20 \mathrm{mg}, \mathrm{H} 2$ blocker (ranitidine $50 \mathrm{mg}$ ), and (diphenhydramine $10 \mathrm{mg}$ ). Ranitidine and diphenhydramine are modifications added to antiemetic premedication protocol to prevent nausea and vomiting incidence on patient. Ranitidine inhibits $\mathrm{H} 2$ receptors and minimizes gastric acids secretion resulting in preventing

Table 3 The Analysis of Antiemetic Premedication Timing on Incident of Acute Vomiting

\begin{tabular}{llcccc}
\hline \multirow{2}{*}{ Cycle } & \multirow{2}{*}{ Antiemetic Premedication Timing } & Vomiting & Negligible & p \\
\cline { 3 - 4 } & & Specific time & n (patient) & n (patient) & \\
\hline \multirow{2}{*}{2} & Unspecific time & Specific time & 11 & 6 & 0,498 \\
& Unspecific time & 0 & 52 & $<0.05$ \\
& Specific time & 16 & 13 & $<0.05$ \\
\hline
\end{tabular}

*This research used Mann-Whitney test; Unspecific antiemetic premedication timing was associated with a greater prevalence of acute vomiting in second and third cycles of chemotherapy with $\mathrm{p}<0.05$, but not in first cycle of chemotherapy with $\mathrm{p}=0.498$. 
Table 4 The Analysis of Antiemetic Premedication Timing on Incident of Delayed Nausea

\begin{tabular}{|c|c|c|c|c|}
\hline \multirow{2}{*}{ Cycle } & \multirow{2}{*}{ Antiemetic Premedication Timing } & Nausea & Negligible & \multirow{2}{*}{$\mathbf{p}$} \\
\hline & & n (patient) & n (patient) & \\
\hline \multirow[t]{2}{*}{1} & Specific time & 3 & 3 & \multirow{2}{*}{$<0.05$} \\
\hline & Unspecific time & 59 & 4 & \\
\hline \multirow[t]{2}{*}{2} & Specific time & 6 & 7 & \multirow{2}{*}{$<0.05$} \\
\hline & Unspecific time & 53 & 3 & \\
\hline \multirow[t]{2}{*}{3} & Specific time & 21 & 10 & \multirow{2}{*}{$<0.05$} \\
\hline & Unspecific time & 35 & 3 & \\
\hline
\end{tabular}

*This research used Mann-Whitney test; Specific time administration of antiemetic treatment was associated with lower prevalence of delayed nausea all cycles chemotherapy with $\mathrm{p}<0.05$.

nausea and vomiting, while diphenhydramine inhibits $\mathrm{H} 1$ receptors and to reduce vestibular stimulation and thus preventing nausea and vomiting. ${ }^{20}$ It was confirmed that the administration of antiemetic premedication was not effective on HEC. However, the administration of antiemetic premedication at a specific time might reduce nausea and vomiting incidence on patients.

These findings are similar to those seen in previous research. It has previously been observed that the administration of high emetogenic chemotherapy frequently caused delayed CINV rather than acute CINV. The administration of antiemetics in controlling delayed CINV might work less optimally. Complete protection from acute and delayed nausea in the initial cycle of chemotherapy were $60 \%$ and $45 \%$, accordingly, for great emetic risk chemotherapy and the rates were advanced in the whole cycles. ${ }^{27-30}$ The incidence of acute and delayed CINV during first, second, and third cycles of chemotherapy could reduce the occurence and severity of acute nausea but not delayed nausea. In the incidence of vomiting, the regimentation could also reduce the incidence and severity of both acute and delayed vomiting (the response is greater than in nausea). Patient at high risk for CINV failed to achieve good nausea control. ${ }^{31}$ The use of premedication antiemetic has reduced the incidence of vomiting, but $30-60 \%$ of the patients still experienced either acute or delayed of nausea. ${ }^{4}$ This study focused on the timing of antiemetic premedication for the incidence of acute CINV and delayed CINV. Breakthrough CINV is nausea and vomiting incidence

Table 5 The Analysis of Antiemetic Premedication Timing on Incident of Delayed Vomiting

\begin{tabular}{clccc}
\hline \multirow{2}{*}{ Cycle } & \multirow{2}{*}{ Antiemetic Premedication Timing } & Vomiting & Negligible & \multirow{2}{*}{$\mathbf{p}$} \\
\cline { 3 - 4 } & & $\mathbf{n}$ (patient) & $\mathbf{n}$ (patient) & \\
\hline \multirow{2}{*}{2} & Specific time & 0 & 6 & \multirow{2}{*}{0.100} \\
& Unspecific time & 26 & 37 & \\
& Specific time & 2 & 11 & $<0.05$ \\
& Unspecific time & 26 & 30 & \\
& Specific time & 8 & 23 & $<0.05$ \\
& Unspecific time & 23 & 15 & \\
\hline
\end{tabular}

*This research used Mann-Whitney test; Specific time administration of antiemetic treatment was associated with lower prevalence of delayed vomiting in second and third cycles chemotherapy with $\mathrm{p}<0.05$, but not in first cycle of chemotherapy with $\mathrm{p}=0.100$. 
for 5 days on patients receiving emetic prophylaxis that requires rescue antiemetic as additional therapy to control nausea and vomiting incidence. Breakthrough CINV will not be discussed in this study. Anticipatory $\mathrm{CINV}$ is nausea and vomiting incidence that occurs between the cycles of chemotherapy and is associated with previous CINV. ${ }^{32}$ Anticipatory CINV was also excluded from the discussion because it occured before each cycle of chemotherapy which was beyond our observation time period.

The research findings here provide further evidence that specific time administration of antiemetic drugs produces important benefits in reducing CINV among people treated with emetogenic chemotherapy for breast cancer. The results emphasize the need to schedule workflows to improve the timeliness of antiemetic treatment provided in this setting. Possible approaches to explore could involve schedule workflow for dispensing and delivery of antiemetic drugs, more involvement from pharmacists in the processes of preparing the medications for administration (currently undertaken by nursing staff), greater education for nursing and medical staff about the importance of specific antiemetic treatment timing, and greater standardization of practices overall. The effects of scheduled workflow and changes to practice should be re-assessed in future research. If more specific time administration of the antiemetic drugs cannot produce a more robust response in reducing delayed phase CINV, especially in cycles after the initial treatment, it is also possible that changes to the antiemetic treatment regimen may need to be considered and evaluated.

This research study has a range of limitations. The sample size was small and some participants declined to participate. The study design did not explore or document the reasons for unspecific time administration of antiemetic treatments, and the protocol was not sufficiently powered to allow detailed exploration of the effects associated with different category of chemotherapy regimens. Randomized controlled trial (RCT) study was not carried out since the objective of this study was to analyse the effect of antiemetic premedication timing on nausea and vomiting incidence with the limited number of nurses. Future research studies could be designed to address these limitations and to provide additional data to explore these aspects of this clinically important issue.

\section{Conclusion}

Specific time administration of antiemetic premedication may minimize the incidence of nausea and vomiting. This study suggests that scheduled workflow and other approaches to increase the timeliness of antiemetic treatment may enhance protection against CINV for people treated with emetogenic chemotherapy for breast cancer, potentially improving quality of life and improving outcomes.

\section{Funding}

This research is partially funded by Taher Professorship programme to Prof. Dr. apt. Suharjono, MS.

\section{Conflict of Interest}

The authors declared no potential conflicts of interest with respect to the research, authorship, and/or publication of this article.

\section{References}

1. Setiowati DAI, Tanggo EH, Soebijanto RI. Hubungan antara pemakaian KB hormonal dengan kejadian kanker payudara di poli onkologi satu atap RSUD Dr. Soetomo, Februari-April 2015. Indones J Cancer. 2016;10(1):11-7. doi: 10.33371/ijoc.v10i 1.409 
2. Lee HB, Han W. Unique features of young age breast cancer and its management. J Breast Cancer. 2014;17(4):301-7. doi: 10. 4048/jbc.2014.17.4.301

3. Klein J, Tran W, Watkins E, Vesprini D, Wright FC, Hong NJL, et al. Locally advanced breast cancer treated with neoadjuvant chemotherapy and adjuvant radiotherapy: A retrospective cohort analysis. BMC Cancer. 2019;19(1):306. doi: 10.1186/s12885-019-5499-2

4. Rao KV, Faso A. Chemotherapyinduced nausea and vomiting: Optimizing prevention and management. Am Health Drug Benefits. 2012;5(4):232-40.

5. Dipiro J, Burns M, Scwinghammer T, Wells B, Malone P, Kolesar J. Pharmacotherapy principles and practice $4^{\text {th }}$ edition. New York: The McGraw-Hill Companies Inc; 2016.

6. Aapro M. CINV: Still troubling patients after all these years. Support Care Cancer. 2018;26(1):5-9. oi: 10.1007/s00520-0184131-3

7. Hayashi T, Shimokawa M, Matsuo K, Miyoshi T, Toriyama Y, Yokota C, et al. Risk factors for delayed chemotherapyinduced nausea and vomiting with lowemetic-risk chemotherapy: A prospective, observational, multicenter study. Cancer Manag Res. 2018;10:4249-55. doi: 10.21 47/CMAR.S176574

8. Pluzanski A, Kalinka E, Lacko A, Rubach M. Prevention of chemotherapyinduced nausea and vomiting — standards versus clinical practice. Oncol Clin Pract. 2016;12(4):153-7. doi: 10.5603/OCP.201 6.0002

9. Molassiotis A,Aapro M,Dicato M, Gascon $\mathrm{P}$, Novoa SA, Isambert $\mathrm{N}$, et al. Evaluation of risk factors predicting chemotherapyrelated nausea and vomiting: Results from a European prospective observational study. J Pain Symptom Manage. 2014;47 (5):839-48. doi: 10.1016/j.jpainsymman.
2013.06.012

10. Kawazoe H, Murakami A, Yamashita M, Nishiyama K, Kobayashi K, Komatsu S, et al. Patient-related risk factors for nausea and vomiting with standard antiemetics in patients with breast cancer receiving anthracycline-based chemotherapy: A retrospective observational study. Clin Ther. 2018;40(12):2170-9. doi: 10.1016/ j.clinthera.2018.10.004

11. Hesketh PJ, Kris MG, Basch E, Bohlke K, Barbour SY, Clark RA, et al. Antiemetics: American Society of Clinical Oncology clinical practice guideline update. J Clin Oncol. 2017;35(28):3240-61. doi: 10.120 0/JCO.2017.74.4789

12. Jordan K, Warr DG, Hinke A, Sun L, Hesketh PJ. Defining the efficacy of neurokinin-1 receptor antagonists in controlling chemotherapy-induced nausea and vomiting in different emetogenic settings - A meta-analysis. Support Care Cancer. 2016;24(5):1941-54. doi: 10.100 7/s00520-015-2990-4

13. Zaidan M, Soufi L, Hafeez M, Abdelwahid M, Rasul KI. Assessing prescribing patterns for the prevention of chemotherapy-induced nausea and vomiting in the national center for cancer care and research. Saudi Pharm J. 2015;23(4):381-7. doi: 10.1016/j.jsps. 2015.01.003

14. Bourdeanu L, Frankel P, Yu W, Hendrix G, Pal S, BadrL, etal. Chemotherapy-induced nausea and vomiting in Asian women with breast cancer receiving anthracyclinebased adjuvant chemotherapy. J Support Oncol. 2012;10(4):149-54. doi: 10.1016/j. suponc.201 1.10.0 07

15. Tageja N, Groninger H. Chemotherapyinduced nausea and vomiting \#285. J Palliative Med. 2014;17(12):1400-2. doi: 10.1089/jpm.2014.9392

16. Costa AL, Abreu C, Pacheco TR, Macedo D, Sousa AR, Pulido C, et al. Prevention 
of nausea and vomiting in patients undergoing oral anticancer therapies for solid tumors. Biomed Res Int. 2015;2015: 309601. doi: 10.1155/2015/309601

17. Rapoport BL. Delayed chemotherapyinduced nausea and vomiting: Pathogenesis, incidence, and current management. Frontiers Pharmacol. 2017; 8:19. doi: 10.3389/fphar.2017.00019

18. Schwartzberg LS, McLaughlin T, Geller RB, Gabrail NY, Marks SM. Real-world efficacy: Intravenous palonosetron three-drug regimen for chemotherapyinduced nausea and vomiting with highly emetogenic chemotherapy. J Comp Eff Res. 2018;7(12):1161-70. doi: 10.2217/ cer-2018-00 89.

19. Berger MJ, Ettinger DS, Aston J, Barbour $\mathrm{S}$, Bergsbaken J, Bierman PJ, et al. NCCN Guidelines Insights: Antiemesis, version 2.2017 featured updates to the NCCN guidelines. J Natl Compr Canc Netw. 2017;15(7):883-93. doi: 10.6004/ jncen.2017.0117

20. Corbett A, Dana W, Fuller M, Gallagher J, Golembiewski J, Gonzales J, et al. Drug information handbook with international trade names index twenty $3^{\text {rd }}$ edition. United States: Wolters Kluwer Health; 2015.

21. Lilley L, Snyder J, Collins S. Pharmacology and the nursing process, $9^{\text {th }}$ edition. USA: Elsevier Inc; 2020.

22. Ueda H, Shimono C, Nishimura T, Shimamoto M, Yamaue H. Palonosetron exhibits higher total control rate compared to first generation serotonin antagonists and improves appetite in delayed phase chemotherapy induced nausea and vomiting. Mol Clin Oncol. 2014;2(3): 375-9. doi: 10.3892/mco.20 4.263

23. National Cancer Institute. In: Agency BC cancer system management guidelines: Cancer related nausea and vomiting 2010 [Accessed on: 12 December 2019].
Available at: http://www.bccancer.bc.ca/ nursingsite/Documents/11.\%20Nausea $\%$ 20and\%20Vomiting.pdf

24. Setyowibowo H, Purba FD, Hunfeld JA, Iskandarsyah A, Sadarjoen SS, Passchier J, et al. Quality of life and health status of Indonesian women with breast cancer symptoms before the definitive diagnosis: A comparison with Indonesian women in general. PLoS One. 2018;13(7):e200966. doi: 10.1371/journal.pone.0200966

25. Phillips RS, Friend AJ, Gibson F, Houghton E, Gopaul S, Craig JV, et al. Antiemetic medication for prevention and treatment of chemotherapy-induced nausea and vomiting in childhood. Cochrane Database Syst Rev. 2016;2(2):1-100. doi: 10.1002/14651858.CD007786.pub3

26. Salihah N, Mazlan N, Lua PL. Chemotherapy-induced nausea and vomiting: Exploring patients' subjective experience. J Multidiscip Healthc. 2016; 9:145-51. doi: 10.2147/JMDH.S97695

27. Lihara H, Fujii H, Yoshimi C, Yamada M, Suzuki A, Matsuhashi N, et al. Control of chemotherapy-induced nausea in patients receiving outpatient cancer chemotherapy. Int J Clin Oncol. 2016;21(2):409-18. doi: 10.1007/s10147-015-0908-2

28. Yap KYL, Low XH, Chan A. Exploring chemotherapy-induced toxicities through multivariate projection of risk factors: Prediction of nausea and vomiting. Toxicol Res. 2012;28(2):81-91. doi: 10.5487/TR. 2012.28.2.081

29. Janicki P. Management of acute and delayed chemotherapy-induced nausea and vomiting: Role of netupitantpalonosetron combination. Ther Clin Risk Manag. 2016;12:693-9. doi: 10.2147/TC R M.S81126

30. Escobar Y, Cajaraville G, Virizuela J, Álvarez R, Muñoz A, Olariaga O, et al. Incidence of chemotherapy-induced nausea and vomiting with moderately 
emetogenic chemotherapy: ADVICE (Actual Data of Vomiting Incidence by Chemotherapy Evaluation) study. Support Care Cancer. 2015;23(9):2833-40. doi: 10.1007/s0 0520-015-2809-3

31. Dranitsaris G, Mazzarello S, Smith S, Vandermeer L, Bouganim N, Clemons $\mathrm{M}$. Measuring the impact of guidelinebased antiemetic therapy on nausea and vomiting control in breast cancer patients with multiple risk factors. Support Care Cancer. 2016;24(4):1563-9. doi: 10.1007 /s00520-015-2944-x

32. Navari RM. Treatment of breakthrough and refractory chemotherapy-induced nausea and vomiting. Biomed Res Int. 2015;2015:595894. doi: 10.1155/2015/59 5894 